Article

\title{
The Role of University Campuses in Reconnecting Humans to the Biosphere
}

\author{
Johan Colding ${ }^{1,2}$ and Stephan Barthel $2,3, *$ \\ 1 The Beijer Institute of Ecological Economics, Royal Swedish Academy of Sciences, P.O. Box 50005, \\ Stockholm, Sweden; johan.colding@beijer.kva.se \\ 2 Stockholm Resilience Center, Stockholm University, Kräftriket 2B, SE-10691 Stockholm, Sweden \\ 3 Faculty of Engineering and Sustainable Development, University of Gävle, Kungsbäcksvägen 47, \\ Gävle 802 67, Sweden \\ * Correspondence: stephan.barthel@hig.se
}

Received: 13 November 2017; Accepted: 14 December 2017; Published: 19 December 2017

\begin{abstract}
In this paper, we explore the potential for integrating university campuses in a global sustainability agenda for a closer reconnection of urban residents to the biosphere. This calls for a socio-cultural transition that allows universities and colleges to reconnect to the biosphere and become active stewards of the Earth System. Recognizing their pivotal role of fostering coming generations of humans, university campuses represent a unique socio-cultural setting to promote sustainable development in practice. Among others, this involves the nurturing of biodiversity and ecosystem services in the Antropocene era, which is characterized by ongoing climate change and massive loss of biodiversity and ecosystem services. We explore the traditional campus setting, its role as a community for rejuvenating town planning and its role as a governance authority that may promote or retard sustainable development with an ecological focus. We explore the "sustainable" university and describe the campus as an ecosystem and how a resilient campus can be designed to meet the novel and critical challenges of the Anthropocene. We conclude by providing some policy recommendations for higher educational institutes to speed up their ambitions in the area of sustainable biosphere management.
\end{abstract}

Keywords: sustainability; transition; universities; colleges; biosphere; urban; biodiversity; ecosystem services; management

\section{Introduction}

Given the generally poor opportunities that exist for natural reserve establishment and ecological restoration in urban areas, urban biodiversity conservation needs to a higher degree depend on anthropogenic habitats and innovative solutions [1]. In this paper, we discuss the potential for integrating university campuses in a global sustainability transition agenda [2] that aid in paving the way for a more sustainable biosphere. Universities, we argue, hold a particular unique influence on society in that they train and educate people and because they participate in governance at the national and regional level [3]; hence, they represent pivotal socio-cultural settings for practical change in navigation towards a more sustainable future. While sustainable development (SD) entails the three pillars of social, economic and ecological development, our focus in this paper is primarily on the role campuses can play supporting ecological conditions in an increasingly uncertain future given climate change and massive biodiversity loss. We acknowledge the importance of the politics of SD including issues of social justice but such an argument is beyond the scope of this study.

We put forward here that universities and their campus areas can become powerful change agents in the transition towards sustainable development, especially due to that they hold agency to uphold protected niches [4], which are about the functions needed for social-ecological innovations to spread 
easier in society [5]. Such 'protected niches for innovations' [6] often must be shielded, nurtured and empowered in relation to selection pressures in free market environments [7]. Universities and Campus areas, we argue, are actor-arenas that can shield, nurture and empower sustainability innovations to develop enough to get a foothold and successfully compete under the selection pressure of the free market. Here we especially elaborate on ways that universities can contribute to reconnecting humans to the biosphere, meaning how they more concretely can support sustainability transitions of socio-cultural processes of self-concept change, social norm formation and associated behavior that promote, rather than degrade, the global ecological system with all its living beings and their interaction with the elements of the lithosphere, hydrosphere and atmosphere.

In order for the sustainability transitions to go in line with such 're-connection agenda' niche innovations especially must address the socio-psychological aspects of change [8]. A great row of scholars now in-line up with Meadows [9], who uses the idea of 'leverage points' for sustainability transformations, where it is the deep leverage points that are hard to shift but it will be only those that have profound transformational power. Included in Meadows' deep leverage points are the strengthening of human-nature relations [10] and shifts in social norms that structure pro-environmental behavior [11]. As an example, Westley et al. [2] argue that sustainability transitions 'may require radical systemic shifts in deeply held values and beliefs.'

We begin by presenting a background underlying such a "reconnection agenda" and proceed by elaborating on why university campuses may be particularly useful to engage in this agenda, focusing on some key characteristics that distinguish this type of land use from others. Using the design principles of a new Swedish university campus in Stockholm as a backdrop, we envision how future university campuses are to be designed and retrofitted to better reconnect humans to the biosphere. Based on the logics conveyed herein we conclude by suggesting ways forward for the "entrepreneurial university" to more actively partake in a global sustainability agenda.

\section{The Era of Anthropocene}

An increasing number of scientists agree that humans today live in the era of the Anthropocene-a proposed epoch that begun when human activities started to have a significant global impact on the Earth's geology and ecosystems [12]. The term was widely popularized in 2000 by atmospheric chemist and Nobel laureate Paul J. Crutzen, who regards the influence of human behavior on the Earth's atmosphere in recent centuries as so significant as to constitute a new geological epoch. In this era, human development and the enhanced material standard of living for a large proportion of humankind on earth, has in particular since the 1950s predominantly benefitted the industrialized world but has pushed humanity into a new geological era, the Anthropocene, with climate change and massive loss of biodiversity and ecosystem services (BES) that make human conditions less resilient with potential thresholds and tipping points $[13,14]$.

As much as 30 to 50 percent of all Earth's species is estimated to become extinct by the mid-century [15] with a loss of species that is believed to be between 1000 and 10,000 times higher than their natural extinction rate [16]. The severity of the situation is reinforced by the fact that as much as about $60 \%$ of the planet's ecosystem services were deemed degraded or used unsustainably in the first scientific global stocktaking of the world's ecosystem services (Figure 1), performed by the UN Millennium Ecosystem Assessment [17]. 


\begin{tabular}{|c|c|c|}
\hline $\begin{array}{c}\text { PROVISIONING } \\
\text { SERVICES }\end{array}$ & REGULATING & CULTURAL \\
\hline $\begin{array}{c}\text { The "products" } \\
\text { obtained from } \\
\text { ecosystems }\end{array}$ & $\begin{array}{c}\text { Benefits obtained from } \\
\text { the regulation of } \\
\text { ecosystem processes }\end{array}$ & $\begin{array}{c}\text { Nonmaterial benefits } \\
\text { obtained from } \\
\text { ecosystems }\end{array}$ \\
\hline Foods & Climate regulation & Educational \\
Fibers & Flood prevention & Recreational \\
Ornamentals & Erosion control & Sense of place \\
Medicines & Pest control & Spiritual \\
Biofuels & Pollination & Cognitive development \\
Fresh water & Seed dispersal & Stress relief \\
Genetic resources & Disease regulation & Gardening \\
\hline \multicolumn{3}{|c|}{ SUPPORTING } \\
\hline \multicolumn{3}{|c|}{ Services necessary for the production } \\
of all other ecosystem services \\
\multicolumn{3}{|c|}{ Biodiversity } \\
Nutrient recycling \\
Primary productivity
\end{tabular}

Figure 1. Ecosystem services include provisioning services, regulating services, cultural services and supporting services (Source: Millenium Ecosystem Assesment. Ecosystems Human Well-Being: Synthesis; Island Press: Washington, DC, USA, 2005).

As argued by Ruckelshaus et al. [18], later scientific advances in assessing ecosystem services have led to an explosion of interest in BES in both the public and private sectors, something also noticeable in urban spatial planning [19]. This reawakened attention to BES is believed to have a potential to "transform decision-making across vast resource-intensive sectors and human development efforts" [18]. This includes an increasing number of companies that recognize that BES underpins sustainable business practices and the local communities in which they operate [18].

The UN Millennium Ecosystem Assessment helped clarify the significance of BES for human wellbeing and also helped connect the climate issue to ecosystems services [20]. For example, the biosphere has over the past 150 years provided an immense ecosystem service to humanity by absorbing about $50 \%$ of the global carbon dioxide emissions [20]. Folke et al. [20] also point out the interconnectedness of cross-scale global links among such seemingly disparate spheres such as emergent economic markets, biodiversity, land-use change and climate feedbacks that will most likely expose regions to changes in frequencies, magnitude and durations of droughts, fires, storms, floods and other shocks and surprises, that in turn will affect for example, food production, trade and possibly socio-political conditions.

As a remedy to the grand challenges facing humanity in Anthropocene, Folke et al. [20] state that it requires not only cross-UN-organizational collaboration but also explicit multilateral environmental agreements (e.g. UNFCCC), enabling legislation and governmental policies such as UN Conventions, EU Directives, or national guidelines as well as economic support to be able to have an impact in local settings where other issues might be viewed as more urgent. It also calls for new paradigms that allow humans to reconnect to the biosphere and become active stewards of the Earth System as a whole.

In such a global and multi-sector reconnection agenda we may very well ask to what extent and in what ways our present-day and future universities and colleges could partake? Recognizing their pivotal role of fostering coming generations of humans they have, at least in theory, a unique position and a dire responsibility to promote this agenda not only by way of teaching and research in sustainability sciences but as a leading sector in reconnecting humans to the biosphere in the era of Anthropocene. 


\section{The Campus Setting}

The concept of the "university" has its origin in the Medieval Christian setting [21] as a continuation of the interest in learning promoted by monasteries [22]. In Europe, the first universities saw their light in the beginning of the thirteenth century with the universities of Bologna and Paris claiming to be the first ones and with the former being a model for universities in Southern Europe and the latter influencing Northern universities [21].

The word "university" is derived from the Latin universitas magistrorum et scholarium, which according to Encyclopedia Britannica (11th ed.) 1911 was originally employed to denote "any community or corporation regarded under its collective aspect" and which in the latter part of the 14th century came to have the exclusive meaning of "a community of teachers and scholars whose corporate existence had been recognized and sanctioned by civil or ecclesiastical authority or by both".

Generally, the term "university" is used interchangeably to "college." However, in the United States "college" refers to a constituent part of a university, whereas in the United Kingdom and many other parts of the world, a "college" often refers to a higher education provider that does not have university status. There are also other meanings to the term college in the US. On the other hand, a campus (from the Latin word for "field") denotes to the land on which a college or university and related institutional buildings are situated and typically includes libraries, lecture halls, residence halls, student centers, dining halls and park-like settings.

It should also be pointed out that a university often has multiple campuses with a single administration even though considerable distance may separate them. For example, Arizona State University describes itself as "one university in many places," even though the Polytechnic campus is located $40 \mathrm{~km}$ southeast of the Tempe campus. Moreover, many universities cover large tracts of land-something we shall return to in part 4.

\subsection{The Campus as a "Community" for Rejuvenating Town Planning}

Jane Jacobs argued for town planning to focus on the neighborhood level if cities were to be socially rejuvenated, suggesting that the notion of "community" should be given priority in urban sustainability building since a city could be considered as a "hierarchy of communities" [23]. By the same token a campus area with all its buildings and land could be considered to be a community within this hierarchy and sharing with the city as a whole a common interest of providing its inhabitants a sustainable and life-enhancing environment.

We here adopt a place-based definition of the term 'community' based on the Merriam-Webster dictionary as "a group of people who live in the same area (such as a city, town, or neighborhood)." UK-based professor of town planning, Michael Hebbert, argues that while universities in the past very much were boundary-driven in that they were turned inward, modern universities are outward-looking and strive instead to be connected to the rest of the town or city in which they are located. This is even expressed in the architectural form that university buildings take on by facing the city rather than turning their back from the city (Michael Hebbert pers. com. May 23, 2017). Hebbert even argues that this aspiration of socio-spatial connectivity is a symbol for knowledge and that the open boundary characteristic is a metaphor for knowledge transfer between the university and the rest of the city. This idea is congruent with the notion of the "entrepreneurial university" proposed by Barnett [24]. The entrepreneurial university is a 'performative university' and an outcome of neo-liberalism, a globalized worldview of an opening of public services to market disciplines [24]. Hence, in addition to research and teaching the entrepreneurial university encompasses the mission of contributing to economic development [25]. This idea stands in stark contrast to past notions of universities as arenas for metaphysical learning and the university as arena for scientific research [24] -both of which encompass more introspective and inward-looking modes of acquiring knowledge.

It should also be recognized that there has been a steadily decline of state support for higher education universities. In the U.S., for example, public universities have lost 25 percent of their state funding per student since year 2000 [26], forcing them to lean far more heavily on tuition 
revenue. The University of California at Berkeley, one of the leading public research universities in the nation, now receives only about 13 percent of its budget from state appropriations, compared with about 50 percent a few decades ago. This shift from public to private funding support has led many to conclude that we are witnessing the privatization of the public research university. Hence, the outward-looking characteristic of the entrepreneurial university will likely continue as a matter of surviving in a fiercer competitive and neo-liberal political environment.

As recognized by Sedlacek [3] the increased role of academic knowledge transfer to the rest of society is an important factor that "drives universities to multi-task organizations which are in need of new governance structures" [27]. Contribution to regional sustainable development has become yet another part of the universities' activities [28,29].

In this sense, the modern university campus could be viewed as a vital part of the rest of the local communities constituting a city or townscape. In fact, the idea of the open-boundary, entrepreneurial university fits well with the notion that "the social and physical structure of the city should maximize connection between its diverse parts, not minimize it" [30].

\subsection{The University Governance Structure-A Barrier or Opportunity for Sustainability?}

The idea of viewing the campus area as a local community places emphasis on the important function of local authorities in reaching sustainable community objectives [30]. As noted by Smith et al. [30], one of the most important roles of local authorities is the education of their people in environmental issues and responding to their initiatives to achieve sustainability.

Nearly all universities have a board of trustees; a president, chancellor, or rector; at least one vice president, vice-chancellor, or vice-rector; and deans of various divisions. While many public universities have a considerable degree of autonomy regarding financial-, research- and pedagogical obligations, they are ruled over by government-run higher education boards that review financial requests and budget proposals and allocate funds for each university in the system. Private universities, on the other hand, are privately funded and generally have broader independence from state policies although they may have less independence from business corporations depending on the source of their finances.

It should be pointed out, though, that governance frameworks play an important role in acting as a barrier or opportunity to effectively present the sustainability agenda to campus stakeholders [31]. First, university leaders and staff must be empowered to catalyze and implement new paradigms and ensure that sustainable development (SD) is the 'Golden Thread' throughout the entire university system [32]. However, given that they are ruled over by federal and local governments, or in some cases by business corporations, or even presidents, they must be given the freedom to do so.

While many academics view the "entrepreneurial university" as a threat to the traditional integrity of the university by losing its role as an independent critic of society [25], one could at the same time view the "entrepreneurial university" as a university that is able to not only cross over physical boundaries but also to cross over disciplinary boundaries. In recognition of that higher education is generally organized into highly specialized areas of knowledge and traditional disciplines, designing a sustainable human future requires what Cortese [33] calls "a paradigm shift toward a systemic perspective emphasizing collaboration and cooperation. Hence, the "entrepreneurial university" needs to be a seat for higher education that is geared at producing knowledge of practical value for finding solutions to present-day grave problems and challenges, such as how to more effectively deal with the root causes of human behavior that results in climate change and the massive loss of global biodiversity. Hence, is it possible for a university or college campus to become a nucleus for rejuvenating town planning by reconnecting humans and cities to the biosphere? This question is particularly relevant since the momentum towards the emergence of an 'entrepreneurial university' is considered to be exceptionally strong and since "its development poses important institutional and governance questions for those involved" [25]. Pivotal in such a development, however, is to make sure that traditional academic subjects are not replaced by more "populist" ones—-threatening academic 
freedom and integrity. This is an immanent risk with a development towards solely entrepreneurial universities. Hence, a mix of inward and outward-looking universities is important to nurture.

\subsection{The "Sustainable" University}

Entrepreneurial universities are important governance actors in promoting sustainable development goals since they provide expertise, knowhow and contribute to regional development [3]. Universities could therefore play a role to make these goals possible in education, research, policy formation and information exchange. University leaders have an important mission to fill by initiating and supporting mobilization of internal and external resources to achieve this (http:/ / ulsf.org/talloires-declaration/).

As a community the role of the university in advancing the sustainability agenda cannot be under-estimated since it is often recognized that achieving societal change is best pursued at the level of groups and local communities [31,34]. To define what constitutes a sustainable university is no straightforward task though. Since the 1987 Brundtland Report, the concept has shifted to focus more on economic and social development and environmental protection for future generations. Velazques et al. [35] have defined a sustainable university as: "A higher educational institution, as a whole or as a part, that addresses, involves and promotes, on a regional or a global level, the minimization of negative environmental, economic, societal and health effects generated in the use of their resources in order to fulfil its functions of teaching, research, outreach and partnership and stewardship in ways to help society make the transition to sustainable life-styles." Cortese [36] envisions such a university to operate as a fully integrated community in itself that models social and ecological sustainability and having an ability to spread this idea to the local, regional and global communities in which it is embedded.

Lozano et al. [32] list fourteen examples of international initiatives taken in higher education to foster sustainable development. One is the Talloires Declaration that was instituted in 1990 in Talloires, France and declaring that institutions of higher learning should be world leaders in developing and creating SD and focusing on the relationship among government, universities and firms-referred to as the "triple helix" [25]. The Talloires Declaration has been signed by presidents, rectors and vice chancellors of universities from all regions of the world and has in large an environmental sustainability focus, recognizing "the unprecedented scale and speed of environmental pollution and degradation and the depletion of natural resources" (http:/ /ulsf.org/talloires-declaration/).

Another example constitutes the Turin Declaration that was launched in 2009 at the G8 University summit in Turin, Italy and emphasizing that sustainability cannot be achieved merely by engaging natural sciences but must also engage life sciences, social sciences and the humanities [32].

In spite of an increasing number of universities becoming engaged with Sustainable Development (SD), Lozano et al. [32] found that most higher education institutions (HEIs) continue to be traditional, relying upon Newtonian and Cartesian reductionist and mechanistic paradigms. In an analysis of eleven declarations, charters and partnerships developed for HEIs, they found that universities are still lagging behind private companies in helping societies become more sustainable. Out of 14,000 universities, only 15 had published sustainability reports [37], in comparison to 2911 companies that had published such reports between 1999 and 2011 [32].

Many universities are also engaged in so called campus sustainability assessments (CSAs) that are used as tools for identifying best practices, communicating goals and experiences and measuring progress towards achieving the concept of a sustainable campus. In a review by Sonetti et al. [38] it was shown that CSAs are biased mainly in measuring energy efficiency indicators and that there is a need for developing indicators beyond this. Suffice it to say, while universities, at least in theory could act as important transition agents toward achieving sustainable development more widely in society their track record in the area seems meagre.

Some of the reasons for this has been pondered upon by Lozano et al. [32], including a lack of SD awareness, insecurity and threat to academic credibility from teachers, over-crowded curricula, lack of 
support, SD considered to have little or no relevance to the course or discipline and uncertainty of the efforts required to engage with and incorporate SD.

\section{The Campus as an "Ecosystem"}

University and college campuses often cover quite large tracts of land, in some cases even containing golf courses (e.g. Table 1).

Table 1. The campus environment at the Ohio State University. Based on "The Ohio State University—Statistical Summary." Autumn 2016. Retrieved 18 April 2017 at https:/ /www.osu.edu/ osutoday/stuinfo.php.

\begin{tabular}{ll}
\hline Columbus campus & 1904 acres \\
Campuses at Lima, Mansfield, Marion and Newark & 1482 acres \\
OARDC \& ATI & 8630 acres \\
Molly Caren Agricultural Center & 2092 acres \\
Don Scott Airport & 1396 acres \\
Golf courses & 486 acres \\
Miscellaneous & 487 acres \\
\hline Total & 16,477 acres \\
\hline
\end{tabular}

The Berry College (Georgia) is considered to be the world's largest contiguous college campus. Besides entailing 47 primary campus buildings, it spans more than 27,000 acres of woodlands, meadows and streams (http:/ / www.berry.edu/quickfacts/).

The university of Oxford holds a 70-acre (28 ha) parkland area in the northeast of the city. As well as providing gardens and exotic plants, theses parks also contains sites of special interest including a genetic garden, an experimental garden and a botanical garden, containing over 8000 different plant species and representing one of the most diverse collections of plants in the world. The Harcourt Arboretum is a 130-acre ( $53 \mathrm{ha})$ site six miles $(10 \mathrm{~km})$ south of the city that includes native woodland and 67 acres (27 hectares) of meadow. Moreover, the 1000-acre $\left(4.0 \mathrm{~km}^{2}\right)$ Wytham Woods are owned by the university and used for research in zoology and climate change.

Krasny and Delia [39] have suggested natural area stewardship as part of campus sustainability. They define such stewardship as "physical work by a group of people to restore and maintain open space and natural areas" [39], arguing for a greater student involvement in nature-based sustainability efforts. They claim that such stewardship not only provides physical benefits to the campus environment through direct management inputs (e.g. tree planting) but also can enhance students' sense of place and play a role in students' mental well-being. Sense of place signifies a sense of 'belonging' and of emotional attachment to a place [40]. In fact, Krasny and Delia [39] envision a Biophilia University by engaging students in hands-on environmental management of university campuses. The concept of 'biophilia' draws on the work of E. O. Wilson and Stephen Kellert [41,42] which claims that humans possess a genetically in-wired attraction to certain aspects of the natural environment and that their well-being depends, to a great extent, on the relationships with the surrounding natural world [43].

There is ample evidence showing that natural areas can enhance students' authentic learning opportunities of biodiversity [44,45]. As noted by Jones [43] schools, colleges and universities are settings with a potential to offset the present human disconnection of nature and instead restore the emotional affinity with nature. Hence, the natural areas of the university campus can be regarded as a place where learning occurs. One example constitutes the Wilma H. Schiermeier Olentangy River Wetland Research Park which is a large-scale aquatic research facility located along the northern edge of the Columbus campus at the Ohio State University. This research park is home to the School of Environment and Natural Resources' aquatics program and is a gateway to research, teaching and outreach related to water resources at the university. Faculty, staff and students at 
the Schiermeier Wetland Park, pursue basic and applied research at multiple levels of ecological organization, ranging from populations to ecosystems to landscapes and the wetland [46]. The public was deeply involved in the creation of this site with volunteers assisting in the planting of wetland plants and the constructing of more than one-half mile of boardwalks through the experimental wetlands, providing students and other researchers to move through the wetland without disrupting ongoing experiments [46]. Besides providing a unique opportunity for undergraduate and graduate student training, the Schiermeier Wetlands also provide a service to the community via environmental outreach and extension. In June 2008, the research park was formally designated as the USA's 24th Ramsar Wetland of International Importance in recognition of its diverse flora and fauna.

Another example constitutes the Musahi Institute of Technology in Yokohama, Japan, where a former community-managed forest was restored for purposes of student education and reviving the interest in the disappearing biodiversity rich forests in semi-urban areas of Japan [47].

Higher educational institutions sometimes also serve as important habitats in biological terms [48]. For example, the university campuses of Pune city, India, contains up to half of the city's plant, bird and butterfly species and a quarter of the species are found nowhere else, despite that these campuses only cover some 5\% of the land area [49]. Interestingly, Moerman and Estabrook [50] found that species richness of flowering plants in the U.S. was significantly higher in counties with universities than in neighboring counties without universities and associated this phenomenon with a greater presence of botanists over time in university towns that supported plants.

Kyushu University in south-western Japan is another example. It is situated within a small valley dotted with ponds and marshes thick with reeds and water lilies and with pines and oaks covering the slopes. More than $40 \%$ of Kyushu's 275 -hectare campus has been converted into a conservation experiment as part of constructing a new campus [51]. In construction of this new campus area, transplantation of ecosystems to maximizing biodiversity and endangered species was used. This activity included students, adult volunteers and schoolchildren. Many higher educational institutions have programmes related to practical biodiversity management on campuses (see e.g. http://www.sustainabilityexchange.ac.uk/eauc_biodiversity_guide).

Lessons from Kyushu University's new campus have been applied to a dam project and a riverbank improvement scheme elsewhere in Japan [51]. In a similar vein the Schiermeier Wetlands plays an essential role in developing science-based solutions to critical issues in water resource management, restoration and conservation. In this way the university campus serves the role as a "living lab" - a research approach that integrates research and innovation processes through the co-creation, exploration, experimentation and evaluation of innovative ideas [52].

\section{The Designed Campus-A Campus for the Anthropocene}

Jones [43] describes how architects have used the principle of biophilia in sustainable building designs, referring to this approach as biophilic design, which is the deliberate attempt to translate an understanding of the proposed inherent human affinity to affiliate with natural systems and processes into the design of the built environment [43]. Biophilic design injects real or simulated natural components into living and working spaces to promote emotional and physical wellness. Biophilic design draws on so called Nature-based Solutions (NBS) [53]. NBS has been in use since 2014 by IUCN in order to promote the role of nature and natural spaces in facing climate adaptation challenges [54]. The core idea of NBS is to use the benefits of ecosystem services to prevent a system from crossing a certain threshold/tipping point, such as critical air temperatures, water shortages, or water levels that could lead to dangerous climate change effects (flooding, heat waves) and are designed to address various environmental challenges while simultaneously providing economic, social and environmental benefits [55].

Research indicates that NBS also could be used in the reshaping of already established buildings and that incremental changes can add up to significant modifications in built form over longer time periods [56]. Such retrofitting may involve quite small adaptations like planting trees to increase 
shading and reducing temperature, installing ponds and domestic rain-water systems and constructing ecological roofs, green walls or similar biotic structures.

Adaptation measures could also be more large-scale and focus on the public realm, including open green spaces like gardens, food cultivation projects and urban green commons [57]. An example of a university that was designed based on social-ecological principles is Campus Albano in Stockholm, Sweden. The planning of Albano was a participatory process involving students, researchers, civic society groups, real estate owners, professional town planners and architects [58-60]. Many of these stakeholders in the participatory planning process were thus not part of the university community. The bearing ideas of the campus include to use the campus area not only as a pretty piece of land but also to use it to perform work to foster broad-based learning about local ecologies, about adaption measures to climate change, as well as about learning about mitigation measures to reduce energy consumption. For instance, it will include novel and diverse energy solutions that will be continuously updated in order to parallel technological innovations. Also, designs should simultaneously support ecological connectivity in the wider landscape, as well as an attempt to create a better socio-spatial connectivity by way of walking and biking for commuting to the campus. Designs also include the greening of buildings with vegetation relating to the proximate historical landscape and the development of new habitats supporting landscape-ecological processes of species migration, pollination and seed-dispersal, hence, designing the campus area to be an ecological 'stepping stone.' It attempts also to support climate adaptation designs that include carbon sequestering and flooding retention (through nature-based solutions like biomass and ponds), which simultaneously support the generation of local biodiversity. Much emphasis is put on how to create affordances for local steward groups to take action in the management of such nature-based designs, including community gardens, food cultivation projects, ponds and green roofs. A novelty is the design thinking about management institutions that invite students and civic organization to actively take part in the management of natural habitats and in so doing, creating living learning laboratories for science education. Hence, the campus area will host urban green commons as institutional design elements [58,61], which allow for participation of local stewards to care for habitats and natural resources in the area. Such designs will not be hidden but are showed-cased in a way so that their visibility increases potential for a mind shift towards a reconnection to the Biosphere. The idea is to foster social learning and simultaneously, to nudge towards a stronger sense of place and pro-environmental behavior. This Campus is currently under construction and will result in 150,000 $\mathrm{m}^{2}$ of building construction, including apartments for students and researchers, with an associated cost of $€ 500$ million [61].

Such living laboratories address the socio-psychological aspects of change as called for by Seyfang and Haxeltine [8] aiming at a shift in norm shaping environments in interplay with systemic shifts in values and beliefs [2]. With their dual missions of generating new knowledge and seeking its applications for the betterment of society, universities can in theory harbour protection of such "social niche innovations." It will, however, require a change in their willingness to imbue their own physical development and campus area management with participatory place-based learning and experimentation [62].

\section{Concluding Remarks}

In this paper, we have focused on what role higher educational institutions could play in reconnecting people to the biosphere as coined by Folke et al. [20]. Suffice it to say we contend with the view of Stephens et al. [63] that universities could play a much more active role as change agents for sustainability in different cultures and contexts. Given their pivotal role in society and the potential for mutual learning, higher education platforms have a unique potential to catalyze "multipliers of sustainability impacting on a societal transition towards sustainability" [43].

However, such a role entails that campuses become much more re-oriented or expanded to contribute more explicitly to societal needs and challenges [64]; hence, the 'entrepreneurial university' is probably best suited in fulfilling this mission. At the same time, this type of university cannot 
solely replace the more inward-looking universities-the nurturing of a mix of universities is a more resilient governance aim for policy makers. More studies should also be devoted to what role the entrepreneurial university can play in promoting social justice in surrounding communities.

While many universities already today have undertaken a number of Sustainable Development initiatives and an increasing number of universities is becoming engaged with $\mathrm{SD}$, a large-scale review of declarations, charters and partnerships developed for higher education institutions (HEIs) show that most continue to be traditional and rely upon Newtonian and Cartesian reductionist and mechanistic paradigms carried out in disciplinary isolation [32]. It is a great setback that many universities are lagging behind companies in helping societies become more sustainable since they have a moral responsibility to educate future generations of humans about the pivotal role that the natural systems have for sustaining human well being and societal development.

As noted by Lozano et al. [32] narrow-minded mental models, coupled with resistance to change and in some cases the self-replicating system of universities, limit the transmission of the SD among disciplines, scholars and university leaders. This is, of course, not a good sign. In conclusion and looking ahead, we propose the following recommendations for higher educational institutes to speed up their ambitions in SD:

- Focus on voluntary stewardship of campus open space and natural areas [39,65]

- Establish university sustainability rating systems on open space and natural area management [39]

- Document the outcomes of hands-on sustainability innovations and environmental stewardship on the campus area and organize this as a relay in that students on a yearly basis can document and monitor changes in sustainability indicators such as shifts in biodiversity over time and space

- Torn the campus into a site showcasing innovative examples of sustainability, for example, by using climate smart technologies in combination with food production and consumption with students and staff members gardening and holding farmers' markets. This concept includes considering the facilitative role that NGOs can play in helping initiate change projects in partnership with universities [66]

- Conceive of students as co-creators of knowledge, gatekeepers to the community and drivers of change [66]

- Assess the campus's natural environment and inform staff, students and the local community, including the disadvantaged groups, about its ecological strengths and shortcomings

- In lack of campus land, engage students in active ecosystem stewardship of natural areas [65,67,68], for example in nearby the campus environment, or in energy saving innovations.

- Combine above ideas with measures that aim to increase access to higher education by economically and socially disadvantaged groups

Acknowledgments: We like to thank the Interreg. Central Baltic Project called: LIVE BALTIC CAMPUS (project nb. CB155), the Beijer Institute of Ecological Economics and the funding secured from MISTRA for the Stockholm Resilience Center, as well as funding from the University of Gävle in supporting part of this work.

Author Contributions: Colding did the empirical ground work of data gathering. Colding and Barthel jointly wrote the paper with Barthel serving as correspondent author.

Conflicts of Interest: The authors declare no conflicts of interest

\section{References}

1. Francis, R.A.; Lorimer, J. Urban reconciliation ecology: The potential of living roofs and walls. J. Environ. Manag. 2011, 92, 1429-1437. [CrossRef] [PubMed]

2. Westley, F.; Olsson, P.; Folke, C.; Homer-Dixon, T.; Vredenburg, H.; Loorbach, D.; Thompson, J.; Nilsson, M.; Lambin, E.; Sendzimir, J.; et al. Tipping toward sustainability: Emerging pathways of transformation. Ambio 2011, 40, 762-780. [CrossRef] [PubMed]

3. Sedlacek, S. The role of universities in fostering sustainable development at the regional level. J. Clean. Prod. 2013, 48, 74-84. [CrossRef] 
4. Smith, A.; Stirling, A.; Berkhout, F. The governance of sustainable socio-technical transitions. Res. Policy 2005, 34, 1491-1510. [CrossRef]

5. Moore, M.-L.; Tjornbo, O.; Enfors, E.; Knapp, C.; Hodbod, J.; Baggio, J.A.; Norström, A.; Olsson, P.; Biggs, D. Studying the complexity of change: Toward an analytical framework for understanding deliberate socialecological transformations. Ecol. Soc. 2014, 19, 54. [CrossRef]

6. Schot, J.; Geels, F.W. Strategic niche management and sustainable innovation journeys: Theory, findings, research agenda, and policy. Technol. Anal. Strateg. Manag. 2008, 20, 537-554. [CrossRef]

7. Smith, A.; Raven, R. What is protective space? Reconsidering niches in transitions to sustainability. Res. Policy 2012, 41, 1025-1036. [CrossRef]

8. Seyfang, G.; Haxeltine, A. Growing grassroots innovations: Exploring the role of community-based initiatives in governing sustainable energy transitions. Environ. Plan. C. Gov. Policy Space 2012, 30, 381-400. [CrossRef]

9. Meadows, D.H. Leverage points-Places to intervene in a system. In Thinking in Systems: A Primer; Chelsea Green Publishing: White River Junction, VT, USA, 2008; pp. 145-165. ISBN 978-1-84407-78578110796.

10. Ives, C.D.; Giusti, M.; Fischer, J.; Abson, D.J.; Klaniecki, K.; Dorninger, C.; Laudan, J.; Barthel, S.; Abernethy, P.; Martín-López, B.; et al. Human-nature connection: A multidisciplinary review. Curr. Opin. Environ. Sustain. 2017, 26-27, 106-113. [CrossRef]

11. Abson, D.J.; Fischer, J.; Leventon, J.; Newig, J.; Schomerus, T.; Vilsmaier, U.; von Wehrden, H.; Abernethy, P.; Ives, C.D.; Jager, N.W.; et al. Leverage points for sustainability transformation. Ambio 2017, 46, 30-39. [CrossRef] [PubMed]

12. Waters, C.N.; Zalasiewicz, J.; Summerhayes, C.; Barnosky, A.D.; Poirier, C.; Ga uszka, A.; Cearreta, A.; Edgeworth, M.; Ellis, E.C.; Ellis, M.; et al. The Anthropocene is functionally and stratigraphically distinct from the Holocene. Science 2016, 351, aad2622. [CrossRef] [PubMed]

13. Steffen, W.; Crutzen, P.J.; McNeill, J.R. The Anthropocene: Are Humans Now Overwhelming the Great Forces of Nature. AMBIO A. J. Hum. Environ. 2007, 36, 614-621. [CrossRef]

14. Rockström, J.; Steffen, W.; Noone, K.; Persson, Å.; Chapin, F.S.; Lambin, E.F.; Lenton, T.M.; Scheffer, M.; Folke, C.; Schellnhuber, H.J.; et al. A safe operating space for humanity. Nature 2009, 461, 472-475. [CrossRef] [PubMed]

15. Thomas, C.D.; Cameron, A.; Green, R.E.; Bakkenes, M.; Beaumont, L.J.; Collingham, Y.C.; Erasmus, B.F.N.; de Siqueira, M.F.; Grainger, A.; Hannah, L.; et al. Extinction risk from climate change. Nature 2004, 427, 145-148. [CrossRef] [PubMed]

16. How Many Species are We Losing? Available online: http://wwf.panda.org/about_our_earth/biodiversity/ biodiversity / (accessed on 15 December 2017).

17. Millenium Ecosystem Assesment. Ecosystems Human Well-Being: Synthesis; Island Press: Washington, DC, USA, 2005.

18. Ruckelshaus, M.; McKenzie, E.; Tallis, H.; Guerry, A.; Daily, G.; Kareiva, P.; Polasky, S.; Ricketts, T.; Bhagabati, N.; Wood, S.A.; et al. Notes from the field: Lessons learned from using ecosystem service approaches to inform real-world decisions. Ecol. Econ. 2015, 115, 11-21. [CrossRef]

19. Colding, J.; Barthel, S.; Bendt, P.; Snep, R.; van der Knaap, W.; Ernstson, H. Urban green commons: Insights on urban common property systems. Glob. Environ. Chang. 2013, 23, 1039-1051. [CrossRef]

20. Folke, C.; Jansson, Å.; Rockström, J.; Olsson, P.; Carpenter, S.R.; Stuart Chapin, F.; Crépin, A.S.; Daily, G.; Danell, K.; Ebbesson, J.; et al. Reconnecting to the biosphere. Ambio 2011, 40, 719-738. [CrossRef] [PubMed]

21. Scheffler, D. Education and Schooling. In Handbook of Medieval Culture; Classen, A., Ed.; De Gruyter: Berlin, Germany; Boston, MA, USA, 2015; pp. 384-405.

22. Johnson, P. The Renaissance: A Short History; Modern Library Chronicles: New York, NY, USA, 2000.

23. Jacobs, J. The Death and Life of Great American Cities; Random House: New York, NY, USA, 1961.

24. Barnett, R. The coming of the ecological university. Oxf. Rev. Educ. 2011, 37, 439-455. [CrossRef]

25. Etzkowitz, H.; Webster, A.; Gebhardt, C.; Terra, B.R.C. The future of the university and the university of the future: Evolution of ivory tower to entrepreneurial paradigm. Res. Policy 2000, 29, 313-330. [CrossRef]

26. Daniels, J. Commentary: Free the Public Universities. Chronicles High. Educ. 2016, 5. Available online: https:/ / www.chronicle.com/article/Free-the-Public-Universities/236372 (accessed on 16 December 2017).

27. Geuna, A.; Muscio, A. The governance of university knowledge transfer: A critical review of the literature. Minerva 2009, 47, 93-114. [CrossRef] 
28. Hansen, J.A.; Lehmann, M. Agents of change: Universities as development hubs. J. Clean. Prod. 2006, 14, 820-829. [CrossRef]

29. Lehmann, M.; Christensen, P.; Thrane, M.; Jørgensen, T.H. University engagement and regional sustainability initiatives: Some Danish experiences. J. Clean. Prod. 2009, 17, 1067-1074. [CrossRef]

30. Smith, M.; Whitelegg, J.; Williams, N. Greening the Built Environment; Earthscan: London, UK, 1998.

31. Too, L.; Bajracharya, B. Sustainable campus: Engaging the community in sustainability. Int. J. Sustain. High. Educ. 2015, 16, 57-71. [CrossRef]

32. Lozano, R.; Lukman, R.; Lozano, F.J.; Huisingh, D.; Lambrechts, W. Declarations for sustainability in higher education: Becoming better leaders, through addressing the university system. J. Clean. Prod. 2013, 48, 10-19. [CrossRef]

33. Cortese, A.D. The Critical Role of Higher Education in Creating a Sustainable Future. Plan. High. Educ. 2003, 31, 15-22.

34. Berkes, F.; Colding, J.; Folke, C. Navigating Social-Ecological Systems: Building Resilience for Complexity and Change; Cambridge University Press: Cambridge, UK, 2003; p. 393.

35. Velazquez, L.; Munguia, N.; Platt, A.; Taddei, J. Sustainable university: What can be the matter? J. Clean. Prod. 2006, 14, 810-819. [CrossRef]

36. Cortese, A.D. The Critical Role of Higher Education in Creating a Sustainable Future. Plan. High. Educ. 2003, 31, 15-22.

37. Lozano, R. The state of sustainability reporting in universities. Int. J. Sustain. High. Educ. 2011, 12, 67-78. [CrossRef]

38. Sonetti, G.; Lombardi, P.; Chelleri, L. True green and sustainable university campuses? Toward a clusters approach. Sustainability. 2016, 8, 83. [CrossRef]

39. Krasny, M.E.; Delia, J. Natural area stewardship as part of campus sustainability. J. Clean. Prod. 2015, 106, 87-96. [CrossRef]

40. Carmona, M.; Heath, T.; Oc, T.; Tiesdell, S. Public Places-Urban Spaces: The Dimensions of Urban Design; Routledge: Abingdon, UK, 2003; ISBN 0750636327.

41. Kellert, S.R.; Wilson, E.O. The Biophilia Hypothesis; Island Press: Washington, DC, USA, 1993.

42. Wilson, E.O. Biophilia; Harvard College: Cambridge, MA, USA, 1984.

43. Jones, D.R. "The biophilic university": A de-familiarizing organizational metaphor for ecological sustainability? J. Clean. Prod. 2013, 48, 148-165. [CrossRef]

44. Benkowitz, D.; Köhler, K. Perception of Biodiversity-The Impact of School Gardening. In Urban Biodiversity and Design; Wiley-Blackwell: Hoboken, NJ, USA, 2010; pp. 425-440. ISBN 9781444332667.

45. Ito, K.; Fjortoft, I.; Manabe, T.; Masuda, K.; Kamada, M.; Fujiwara, K. Landscape design and children's participation in a Japanese primary school-Planning process of school biotope for 5 years. In Urban Biodiversity and Design; Müller, N., Werner, P., Kelcey, J.G., Eds.; Wiley-Blackwell: West Sussex, UK, 2010; pp. 441-453.

46. Mitsch, W.J.; Wu, X.; Nairn, R.W.; Weihe, P.E.; Wang, N.; Deal, R.; Boucher, C.E. Creating and Restoring Wetlands. Bioscience 1998, 48, 1019-1030. [CrossRef]

47. Kobori, H.; Primack, R.B. Participatory conservation approaches for satoyama, the traditional forest and agricultural landscape of Japan. Ambio 2003, 32, 307-311. [CrossRef] [PubMed]

48. Patwardhan, A.; Nalavade, S.; Sahasrabuddhe, K.; Utkarsh, G. Urban wildlife and protected areas in India. Park Cities Prot. Areas 2001, 11, 28-34.

49. Kulkarni, M.; Dighe, S.; Sawant, A.; Oswal, P.; Sahasrabuddhe, K.; Patwardhan, A. Institutions: Biodiversity hotspots in urban areas. In Tropical Ecosystems: Structure, Diversity and Human Welfare; Oxford and IBH: New Dehli, India, 2001; pp. 693-695.

50. Moerman, D.E.; Estabrook, G.F. The botanist effect: Counties with maximal species richness tend to be home to universities and botanists. J. Biogeogr. 2006, 33, 1969-1974. [CrossRef]

51. Normile, D. Conservation Takes a Front Seat as University Builds New Campus. Science 2004, 305, 329-331. [CrossRef] [PubMed]

52. Almirall, E.; Wareham, J. Living Labs: Arbiters of midand ground-level innovation. Technol. Anal. Strateg. Manag. 2011, 23, 87-102. [CrossRef] 
53. Scott, M.; Lennon, M.; Haase, D.; Kazmierczak, A.; Clabby, G.; Beatley, T. Nature-based solutions for the contemporary city/Re-naturing the city/Reflections on urban landscapes, ecosystems services and nature-based solutions in cities/Multifunctional green infrastructure and climate change adaptation: Brownfield greening as an adaptation strategy for vulnerable communities?/Delivering green infrastructure through planning: Insights from practice in Fingal, Ireland/Planning for biophilic cities: From theory to practice. Plan. Theory Pract. 2016, 17, 267-300. [CrossRef]

54. International Union for Conservation of Nature. Renaturing Cities-Using Nature Based Solutions to Address Urban Challenges; IUCN: Gland, Switzerland, 2014.

55. European Commision. Towards an EU Research and Innovation Policy Agenda for Nature-Based Solutions $\mathcal{E}$ Re-Naturing Cities. Final Report of the Horizon 2020 Expert Group on "Nature-Based Solutions and Re-Naturing Cities" (Full Version); European Commision: Brussels, Belgium, 2015.

56. Mcmanus, R.; Ethington, P.J. Suburbs in transition: New approaches to suburban history. Urban Hist. 2007, 34, 317-337. [CrossRef]

57. Colding, J.; Barthel, S. The potential of "Urban Green Commons" in the resilience building of cities. Ecol. Econ. 2013, 86, 156-166. [CrossRef]

58. Barthel, S.; Colding, J.; Ernstson, H.; Erixon, H.; Grahn, S.; Kärsten, C.; Marcus, L.; Torsvall, J. Principles of Social-Ecological Urbanism. Case Study: Albano Campus, Stockholm; TRITA-ARK-Forskningspublikationer: Stockholm, Sweden, 2013.

59. Erixon, H.; Borgström, S.; Andersson, E. Challenging dichotomies-Exploring resilience as an integrative and operative conceptual framework for large-scale urban green structures. Plan. Theory Pract. 2013, 14, 349-372. [CrossRef]

60. Erixon Aalto, H.; Ernstson, H. Of plants, high lines and horses: Civic groups and designers in the relational articulation of values of urban natures. Landsc. Urban Plan. 2017, 157, 309-321. [CrossRef]

61. Schewenius, M.; Erixon Aalto, H.; Rawaf, R.; Barthel, S.; Colding, J.; Andersson, E. Science Report: Campus Albano-On Integrated Planning and Social-Ecological Urban Design; Stockholm Resilience Centre: Stockholm, Sweden, 2017.

62. Pulkkinen, K.-L. Sustainable Campus Founded on Social-Ecological Synergies. In Orchestrating Regional Innovation Ecosystems_Espoo Innovation Garden; Lappalainen, P., Aalto, U., Markkula, M., Kune, H., Educore, B., Eds.; Aalto University in Cooperation with Laurea University of Applied Sciences and Built Environment Innovations RYM Ltd.: Helsinki, Finland, 2015; pp. 297-308. ISBN 978-952-60-3702-8.

63. Stephens, J.C.; Hernandez, M.E.; Román, M.; Graham, A.C.; Scholz, R.W. Higher education as a change agent for sustainability in different cultures and contexts. Int. J. Sustain. High. Educ. 2008, 9, 317-338. [CrossRef]

64. Stephens, J.C.; Graham, A.C. Toward an empirical research agenda for sustainability in higher education: Exploring the transition management framework. J. Clean. Prod. 2010, 18, 611-618. [CrossRef]

65. Krasny, M.E.; Tidball, K.G. Civic ecology: A pathway for Earth Stewardship in cities. Front. Ecol. Environ. 2012, 10, 267-273. [CrossRef]

66. Müller-Christ, G.; Sterling, S.; Van Dam-Mieras, R.; Adomßent, M.; Fischer, D.; Rieckmann, M. The role of campus, curriculum, and community in higher education for sustainable development-A conference report. J. Clean. Prod. 2014, 62, 134-137. [CrossRef]

67. Colding, J.; Lundberg, J.; Folke, C. Incorporating Green-area User Groups in Urban Ecosystem Management. AMBIO A J. Hum. Environ. 2006, 35, 237-244. [CrossRef]

68. Oldfield, T.E.E.; Smith, R.J.; Harrop, S.R.; Leader-Williams, N. Letters To Nature. Nature 2003, 423, 531-533. [CrossRef] [PubMed]

(C) 2017 by the authors. Licensee MDPI, Basel, Switzerland. This article is an open access article distributed under the terms and conditions of the Creative Commons Attribution (CC BY) license (http:/ / creativecommons.org/licenses/by/4.0/). 